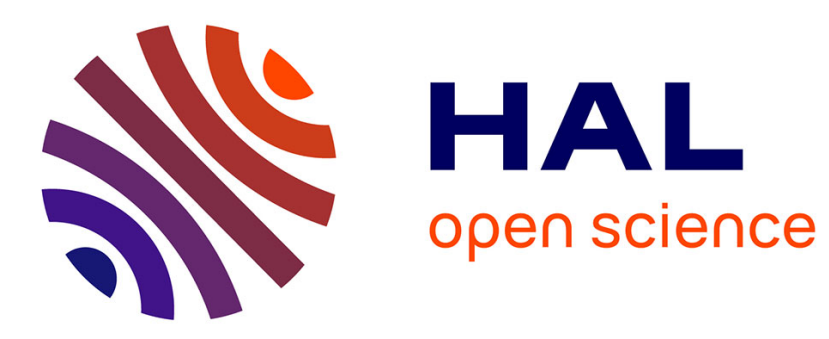

\title{
Acacia tortilis var. raddiana communities in the northwestern Algerian Sahara
}

Abdelkader Nabil Benghanem, Nacera Boucheneb, Salima Benhouhou, Brendan O’Hanrahan, Frédéric Médail

\section{To cite this version:}

Abdelkader Nabil Benghanem, Nacera Boucheneb, Salima Benhouhou, Brendan O'Hanrahan, Frédéric Médail. Acacia tortilis var. raddiana communities in the northwestern Algerian Sahara. Acta Botanica Gallica, 2016, 163 (3), pp.289-306. 10.1080/23818107.2016.1199325 . hal-01444048

\author{
HAL Id: hal-01444048 \\ https://hal.science/hal-01444048
}

Submitted on 21 Feb 2022

HAL is a multi-disciplinary open access archive for the deposit and dissemination of scientific research documents, whether they are published or not. The documents may come from teaching and research institutions in France or abroad, or from public or private research centers.
L'archive ouverte pluridisciplinaire HAL, est destinée au dépôt et à la diffusion de documents scientifiques de niveau recherche, publiés ou non, émanant des établissements d'enseignement et de recherche français ou étrangers, des laboratoires publics ou privés. 


\title{
Acacia tortilis var. raddiana communities in the northwestern Algerian Sahara
}

\author{
Abdelkader Nabil Benghanema ${ }^{a}$ Nacéra Boucheneb ${ }^{b}$, Salima Benhouhouc, Brendan O'Hanrahan ${ }^{d}$ and \\ Frédéric Médaile \\ aDépartement des sciences biologiques et agronomiques, Université Mouloud Mammeri, Tizi-Ouzou, Algeria; b Institut National de Recherche \\ Forestière, Bainem, Cheraga, Algiers, Algeria; 'Département de Botanique, Ecole Nationale Supérieure Agronomique, El Harrach, Algeria; ${ }^{\mathrm{B} B l a r}$ \\ Mhor, 390 Elphin by Lairg, Sutherland, UK; 'Institut Méditerranéen de Biodiversité et d'Ecologie marine et continentale (IMBE), Aix Marseille \\ Université (UMR AMU, CNRS, IRD, AU), Technopôle Arbois-Méditerranée, Bâtiment Villemin, BP 80, Aix-en-Provence, 13545 cedex 4, France
}

\begin{abstract}
The aim of this work is the phytoecological study of the Acacia tortilis var. raddiana desert savanna in the northwestern Algerian Sahara. Sixty-seven relevés were collected for this habitat from an area extending from the northern boundary of Béchar to the southern part of Kerzaz, a latitudinal gradient of $250 \mathrm{~km}$. A detrended correspondence analysis identified two communities represented by 35 and 32 relevés. Canonical correspondence analysis highlighted the topography and the nature of the substratum as the main environmental factors explaining the distribution of the two groups. The most frequent community corresponded to the Acacia tortilis var. raddiana, Panicum turgidum and Foleyola billotii association Quézel 1965. It is associated with large wadi-beds and alluvial plains. This association presents two facies: a saxicolous one characterized by Farsetia occidentalis and Trichodesma calcaratum and a sandy facies with Kickxia aegyptiaca and Brocchia cinerea. The second community corresponds to the Acacia tortilis var. raddiana and Rhus tripartita association Quézel 1965, typical of narrow wadi-beds with rocky substrates. The floristic composition reveals fewer taxa of tropical origin and a reduced list of characteristic species is proposed. Details of the range of the two syntaxa identified are provided. They are compared with the other Acacia tortilis var. raddiana associations described for the Algerian central Sahara.
\end{abstract}

\section{ARTICLE HISTORY}

Received 24 February 2016

Accepted 25 May 2016

KEYWORDS

Acacia tortilis var. raddiana

communities; desert

vegetation; multivariate

analysis; phytosociological

diagnosis; wadi

geomorphology

\section{Introduction}

The vegetation of the Algerian Sahara has long been known for its distinctiveness and phytogeographical interest and complexity. Quézel (1978) indicates the existence of nine biogeographical domains for the Sahara out of 14 for North Africa. An even more detailed phytogeographical description provided by Le Houerou $(1990,1995)$ which, extended to the Sahelian territories, suggests the existence of 16 domains that cover the Sahara. The limits of these phytogeographical subdivisions (zones) are outlined in Figure 1. The vegetation description in the present paper falls into the northwestern Saharan domain of Quézel (1978), corresponding more or less to the same zone proposed by Le Houérou (1990, 1995).

The special character and landscape diversity of the northwestern Sahara has attracted many botanists over the last century (Tits 1925; Maire 1938; Guinet 1954, 1958; Guinet and Sauvage 1954). Tree species are rare in the Sahara and plant communities with Acacia tortilis var. raddiana as the dominant stratum are the most widespread vegetation units in the Saharo-Arabian belt
(Ozenda 1958; Boulos 1995). Acacia tortilis var. raddiana is an African (Sahelo-Sudanian) element (Ross 1981). This species occurs abundantly in all northern and eastern African countries and extends eastward to the Arabian Peninsula (Brenan 1983; Kennenni 1991). In this paper, we used the flora of Ozenda (2004) for species identification. Nomenclature follows Dobignard and Chatelain (2010-2013) for all the species of the present study.

Early descriptions of Acacia communities were provided by Guinochet and Quézel (1954), Quézel and Simonneau (1963), Quézel (1965), Barkoudah and Van Der Sar (1982). In the northwestern Sahara, the "pseudo-steppe" of Acacia tortilis var. raddiana and Panicum turgidum is the main community that occupies non-saline wadi-beds (Guinet 1954; Quézel 1965). Recently, Bensaid, Ait-Mohand, and Echaïb (1996) studied the spatio-temporal dynamics of Acacia tortilis var. raddiana while Benhouhou (1991) and Benghanem (2009) studied the ecology and phytosociology of Acacia tortilis var. raddiana communities in the Ougarta mountains (Figure 2). To date, however, although 


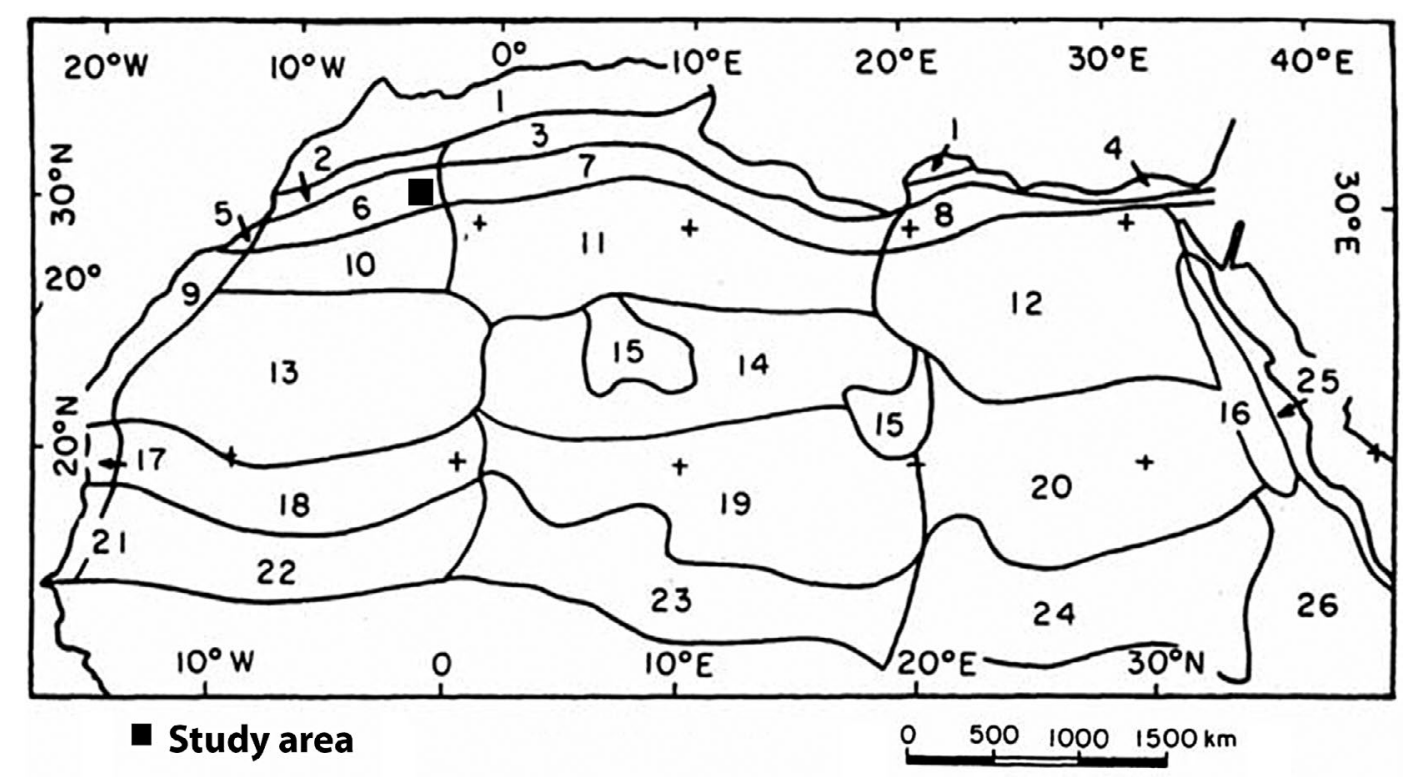

Figure 1. Sketches of the phytogeographical subdivisions of the Sahara and neighbouring territories by Le Houérou (1990, 1995). 1: Mediterranean region (semi-arid to hyper-humid zones); 2: Western arid steppe zone; 3: Central arid steppe zone; 4: Eastern arid steppic zone; 5: Oceanic northern Sahara zone; 6: Western Northern Sahara transition zone; 7: Central Northern Sahara transition zone; 8: Oriental Northern Sahara transition zone; 9: Oceanic central Sahara; 10: Northwestern central Sahara; 11: Northern central Sahara; 12: Northeastern central Sahara; 13: Western central Sahara; 14: Central central Sahara; 15: Central Sahara highlands; 16: Eastern Sahara highlands; 17: Oceanic southern Sahara; 18: Western southern Sahara; 19: Central southern Sahara; 20: Eastern southern Sahara; 21: Oceanic Sahel; 22: Western Sahel; 23: Central Sahel; 24: Eastern Sahel; 25: Eastern Sahara, fringes of the Red Sea; 26: Soudano-Angolan region, Eastern-African domain, mountain zone.

Acacia communities dominate almost all Saharan wadis, relatively few phytosociological and ecological studies of these communities have been carried out in Algeria (Barry, Celles, and Manière 1981; Benhouhou, Dargie, and Gilbert 2003; Gaci 2012; Boucheneb and Benhouhou 2012). This contrasts with some other studies performed in other parts of the Sahara (Danin 1983; Kenneni 1991; Abd El-Ghani and Amer 2003; Al-Atar, El-Sheikh, and Thomas 2012).

The aim of the present study focuses on the phytoecological and phytosociological analysis of the Acacia tortilis var. raddiana communities in the northwestern Sahara, in order to identify the main ecological gradients that structure these ecosystems and to propose a critical analysis of the phytosociological framework proposed by Quézel (1965). Furthermore, a comparison of the associations described with those found in the central Sahara domain in Algeria is made to strengthen the syntaxonomic system of Acacia tortilis var. raddiana communities.

\section{Study area and methodology}

The study area is bounded in the north by a line level with the city of Béchar, while the southern limit is represented by the oasis of Kerzaz; the oasis of BéniAbbès represents an approximately central location. The latter is located $1200 \mathrm{~km}$ southwest of Algiers (Figure 2).

\section{Climate}

Descriptions of climate and bioclimate are based on rainfall and temperature data obtained from the nearest meteorological stations to the study area: Béchar and Béni-Abbès. Data were gathered from the National Meteorological Office (NMO) for a period of 40 years (1967 to 2007) and from Dubief (1959) for an earlier period spanning 24 years (1926 to 1950) (Table 1).

A study of Table 1 shows a decrease in rainfall between the two periods for both Béchar (79.9 $\mathrm{mm}$ to $69.5 \mathrm{~mm}$ ) and Béni-Abbès ( $32.1 \mathrm{~mm}$ to $29.9 \mathrm{~mm}$ ). Similarly, a slight increase in average temperature is observed. Climatic synthesis shows that $\mathrm{Q}_{2}$ values are substantially the same for Béni-Abbès (2.70 and 2.75) for the two periods, with a slight decrease for Béchar (7.13 and 6.45).

The study area is located in the Saharan bioclimate with cold to mild winters for the first period (1926 to 1950) and milder winter for the second period (1967 to 2007).

\section{Geology and geomorphology}

The study area is located at the junction of three geomorphological units: the Great Western Erg, the Guir Hamada and the Ougarta mountains. The Great Western Erg occupies the eastern part of the study area and consists of extensive sand dunes of Quaternary origin (Nedjari 1995). 


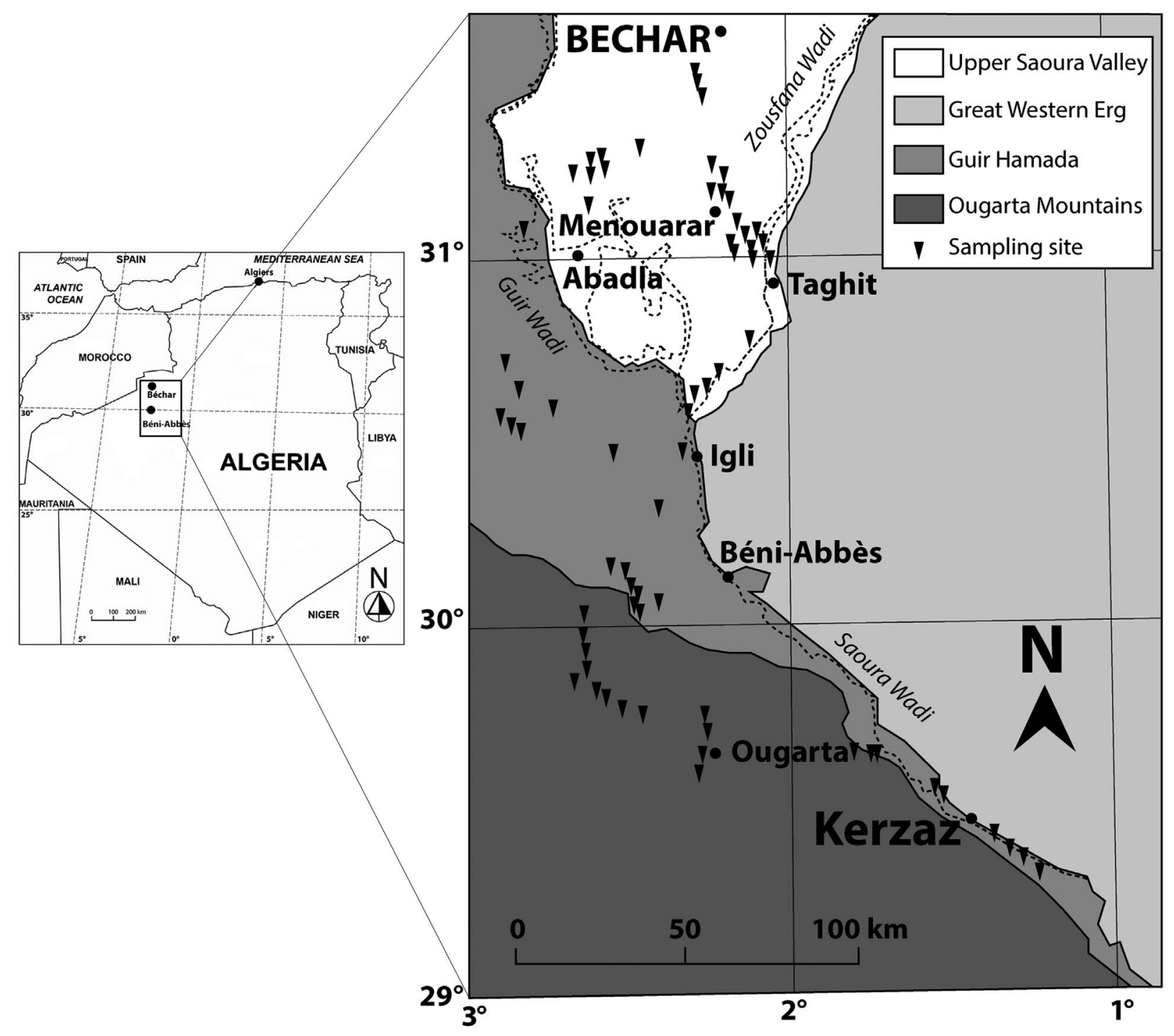

Figure 2. Geographical localization of the study area.

Table 1. Climatic data for the study area.

\begin{tabular}{|c|c|c|c|c|c|c|c|c|}
\hline \multirow[b]{3}{*}{ Stations } & \multicolumn{8}{|c|}{ Period } \\
\hline & \multicolumn{4}{|c|}{ 1926-1950 (Dubief, 1959) } & \multicolumn{4}{|c|}{ 1967-2007 (National Meterological Office) } \\
\hline & $P(\mathrm{~mm})$ & $\mathrm{T}\left({ }^{\circ} \mathrm{C}\right)$ & $\mathrm{Q}_{2}$ & Bioclimate & $P(\mathrm{~mm})$ & $\mathrm{T}\left({ }^{\circ} \mathrm{C}\right)$ & $\mathrm{Q}_{2}$ & Bioclimate \\
\hline Béchar (791 m) & 79.9 & 20.7 & 7.13 & Saharan with cool winter & 69.5 & 21.3 & 6.45 & $\begin{array}{l}\text { Saharan with temperate } \\
\text { winter }\end{array}$ \\
\hline Béni-Abbès (498 m) & 32.1 & 22.8 & 2.75 & Saharan with temperate winter & 29.9 & 23.5 & 2.70 & $\begin{array}{l}\text { Saharan with temperate } \\
\text { winter }\end{array}$ \\
\hline
\end{tabular}

The Guir Hamada, located in the northwestern part of the study area, is a vast rocky platform of about $10-\mathrm{m}$ thick sandstone of Plio-Quaternary origin (Conrad and Roche 1965). The Ougarta mountains are located in the southwestern part of the study area, covering an area of about $6000 \mathrm{~km}^{2}$ of Precambrian sandstones (Ait-Ouali and Nedjari 2006).

Water resources in the study area are represented by unconfined aquifers in the Quaternary terrain of the Guir Hamada and a few aquifer units in the Ougarta mountains (Roche 1973). Occasionally, irregular flooding of wadis in the Ougarta area results in a significant additional water source for the vegetation. Soils of the study area are raw mineral soils - the dominant substrate encountered in Saharan non-saline wadis (Dutil 1971). It is in these mountains that the best developed examples of the Acacia savanna community are encountered.

\section{Sampling and data analyses}

Sampling of the vegetation was carried out in March 2007 and 2008 over an area of about $50,000 \mathrm{~km}^{2}$, stretching over $250 \mathrm{~km}$. During this period, 67 floristic relevés were recorded. These were obtained from various different 
geomorphological wadi units (topography) as well as valleys and alluvial plains. The distribution of relevés is presented in Figure 2.

The quadrat area for the study was $100 \mathrm{~m}^{2}$, which is the standard size for most comparable work in arid zones (Kassas 1953; Quézel 1965; Abd El-Ghani 1998; Benhouhou, Dargie, and Gilbert 2003).

The geomorphological wadi unit is the key factor in the description of these communities (Fossati, Pautou, and Peltier 1998; Benhouhou, Dargie, and Gilbert 2001; Al-Atar, El-Sheikh, and Thomas 2012). The geomorphological units identified and used for this study are: the primary and secondary wadi beds, different terrace levels, valleys and alluvial plains. The aim is to dissect out the relationship between the floristic variability and the various geomorphological facies of the wadi.

The floristic and ecological data collected were submitted to two kinds of multivariate analysis: detrended correspondence analysis (Hill and Gauch 1980) and canonical correspondence analysis (Ter Braak 1987). The software used was PC-ORD (McCune and Mefford 1999). These analyses helped to distinguish the plant communities observed in the study area and also to extract the dominant ecological gradients. Associations described are related to syntaxonomical units proposed by Quézel (1965) according to the phytosociological method of Braun-Blanquet (1952). Finally, a bibliographical review enabled the authors to compare the associations described in this study with all of the Acacia tortilis var. raddiana communities documented to date in the Algerian central Sahara.

\section{Results}

\section{Ecological gradient analyses}

The relevés performed in this study and distributed along the first two axes resulted into two main groups, A with 35 relevés and $B$ with 32 relevés. Eigenvalues were 0.346 for the first axis and 0.259 for the second axis, suggesting that there are at least two gradients at work. Within group A, two sub-groups were distinguished: a1 (with six relevés) and a2 (with six relevés) (Figure 3).

Analysis of the relevés and species distribution along the first axis revealed the appearance of two ecological gradients (Figure 4).

Axis 1 corresponds to a geomorphological gradient that opposes the relevés taken from large wadi beds, bordered by alluvial terraces and fans (negative side), to relevés from narrow rocky wadi beds (positive side) (Figure 3). Hence, the analysis helped to distinguish two major geomorphological units of the "wadi habitat": (i) a unit where the wadi shows both a minor (channel) and a major wadi bed (floodplain), which is characterized by species associated with gravelly sandy substrates such as Panicum turgidum, Citrullus colocynthis and Acanthorrhinum ramosissimum, and (ii) a rocky unit epitomized by woody chasmophils such as Rhus tripartita, Maytenus senegalensis and Ceratolimon feei.

For the second axis, a clear contrast appears between relevés on sandy substrates for the negative part of the axis which feature perennial psammophilous plants such as Kickxia aegyptiaca and therophytes such as Brocchia cinerea, Neurada procumbens and Ifloga spicata. On the positive side of this axis, are located the relevés taken from coarse to gravelly substrates, with high-frequency species here including Trichodesma calcaratum, Farsetia occidentalis and Kebirita roudairei. The distinction between relevés taken from sandy substrates and those from gravelly-coarse substratum highlights the soil texture as the main environmental gradient along the second axis. The projection of two gypsophilic species: Caroxylon vermiculatum and Tetraena alba, reflects minor local edaphic affinities which have limited importance in the structure of the studied communities. The analysis also reveals that the altitudinal variations observed were not discriminative.

A topographic sequence is presented in Figures 5a and $5 b$ to illustrate the distribution of the floristic groups identified in relation to ecological gradients.

\section{Syntaxonomic description}

The phytosociological examination of the data has led to the assigning of the vegetation to two main plant communities: (i) the association with Acacia tortilis var. raddiana, Panicum turgidum and Foleyola billotii Quézel 1965 (group A), and (ii) the association with Acacia tortilis var. raddiana and Rhus tripartita Quézel 1965 (group B) (Figure 3). Within the phytosociological framework established by Quézel (1965) for the northwestern Sahara, these two associations are included into the Antirrhineto-Zillion macropterae alliance Quézel 1965, the Pergularieto-Pulicaretalia order Quézel 1965 and the Pergularieto-Pulicarietea class Quézel 1965.

\section{The Acacia tortilis var. raddiana, Panicum turgidum and Foleyola billotii association Quézel 1965}

This association is characteristic of wadi beds, terraces and sediment fans on gravelly-sandy soils, mainly in the Ougarta mountains, at altitudes between 375 and 650 $\mathrm{m}$ (Figure 6).

Relevés of this association are grouped in Table 2 and are represented by:

The association (A), a chasmophil facies (a1) with Farsetia occidentalis and Trichodesma calcaratum and a psammophil facies (a2) with Kickxia aegyptiaca and Brocchia cinerea. Both of these facies were observed on wadi terraces.

For the relevés made in the same area, among the species proposed by Quézel (1965) as characteristics of the association, seven species of tropical origin were 


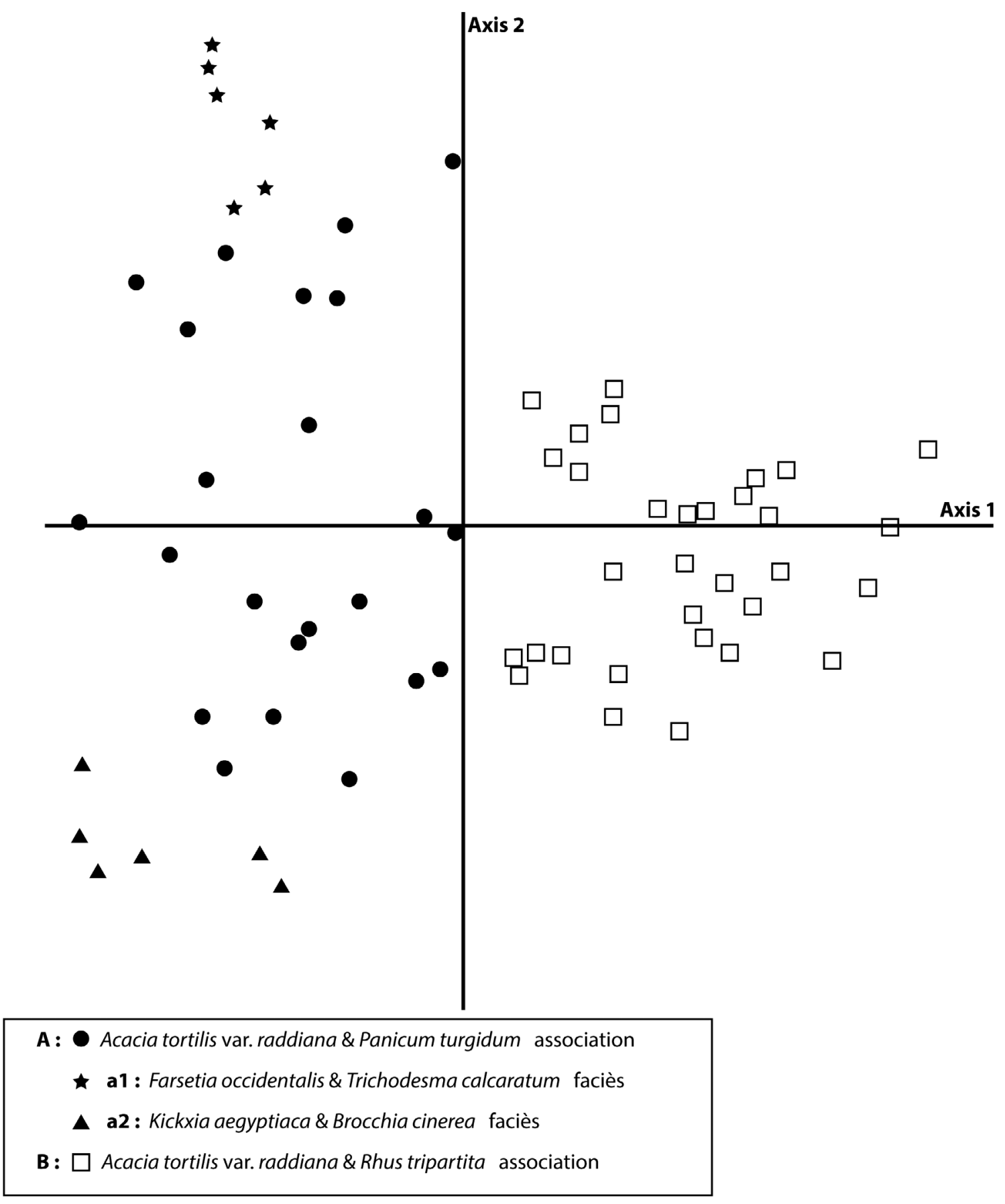

Figure 3. Ordination diagram of a detrended correspondence analysis of 67 relevés of the study area.

absent from those recorded during this study: Caylusea hexagyna, Seetzenia lanata, Maerua crassifolia, Senna italica, Acacia ehrenbergiana, Astragalus akkensis and Lavandula coronopifolia. An endemic species of the southeastern Moroccan desert and the Ougarta mountains, Foleyola billotii, was similarly not recorded.

\section{The Acacia tortilis var. raddiana and $R$ hus tripartita association Quézel 1965}

This association is found on rocky terrain in narrow wadi beds and has been recorded from an altitudinal range between 500 and $690 \mathrm{~m}$ (Figure 7). It has been observed from both rocky wadis of the southern djebel slopes in the Béchar area as well as rocky wadis in the Igli and Taghit region.
With regard to the syntaxonomic level, the analysis of Table 3 shows that this association belongs to the same higher syntaxonomic units as the Acacia tortilis var. raddiana, Panicum turgidum and Foleyola billotii association. It is also distinguished by a large proportion of characteristic species, which are typical of the Atractylion babelii alliance Quézel 1965 and the GymnocarpetoAtractyletalia order Quézel 1965 of rocky terrain and hamada, with this cohort being typified by species such as: Gymnocarpos decandrus, Perralderia coronopifolia, Deverra battandieri and Ceratolimon feei.

Again, for the relevés realized in the same region, among the characteristic species proposed by Quézel (1965) for this association, two tropical species, with low frequency, were notably absent from our relevés: Cenchrus ciliaris and Tricholaena teneriffae. 


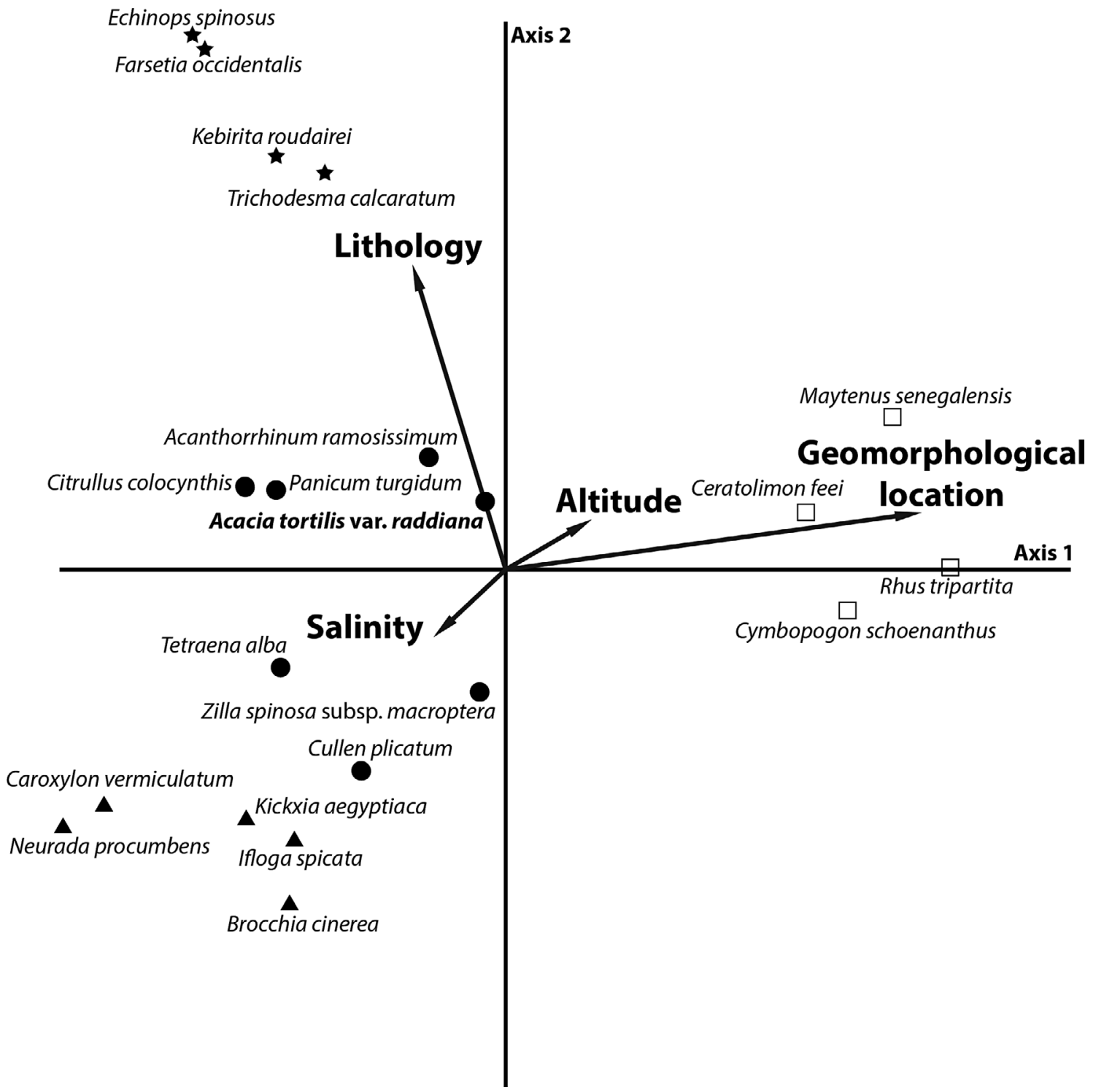

Figure 4. Species scatter and main ecological factors produced by canonical correspondence analysis of the 67 relevés.

(a) Acacia tortilis var. raddiana

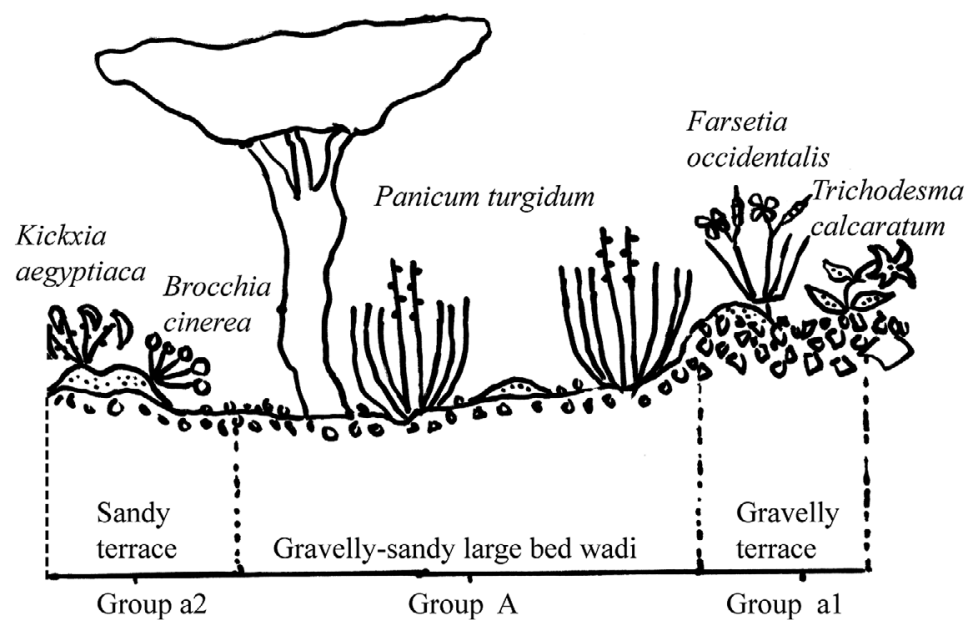

(b) Acacia tortilis var: raddiana

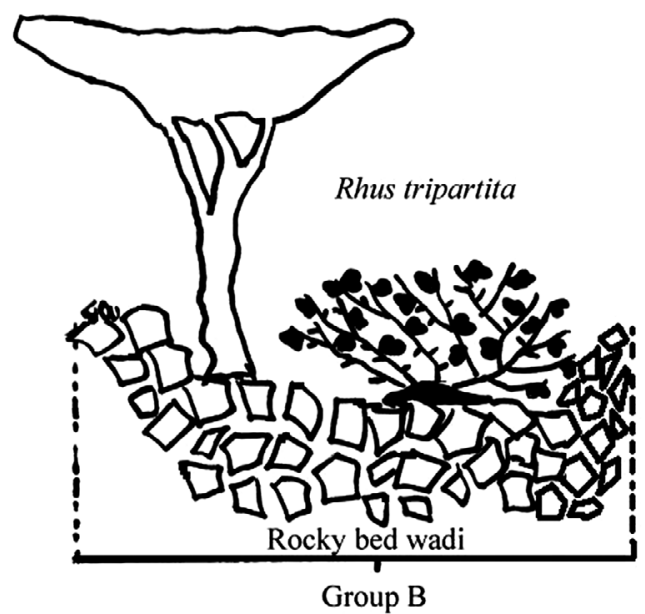

Figure 5. Topographic sequences of (A) the Acacia tortilis var. raddiana, Panicum turgidum and Foleyola billotii association and its two facies; and (B) the Acacia tortilis var. raddiana and Rhus tripartita association. 


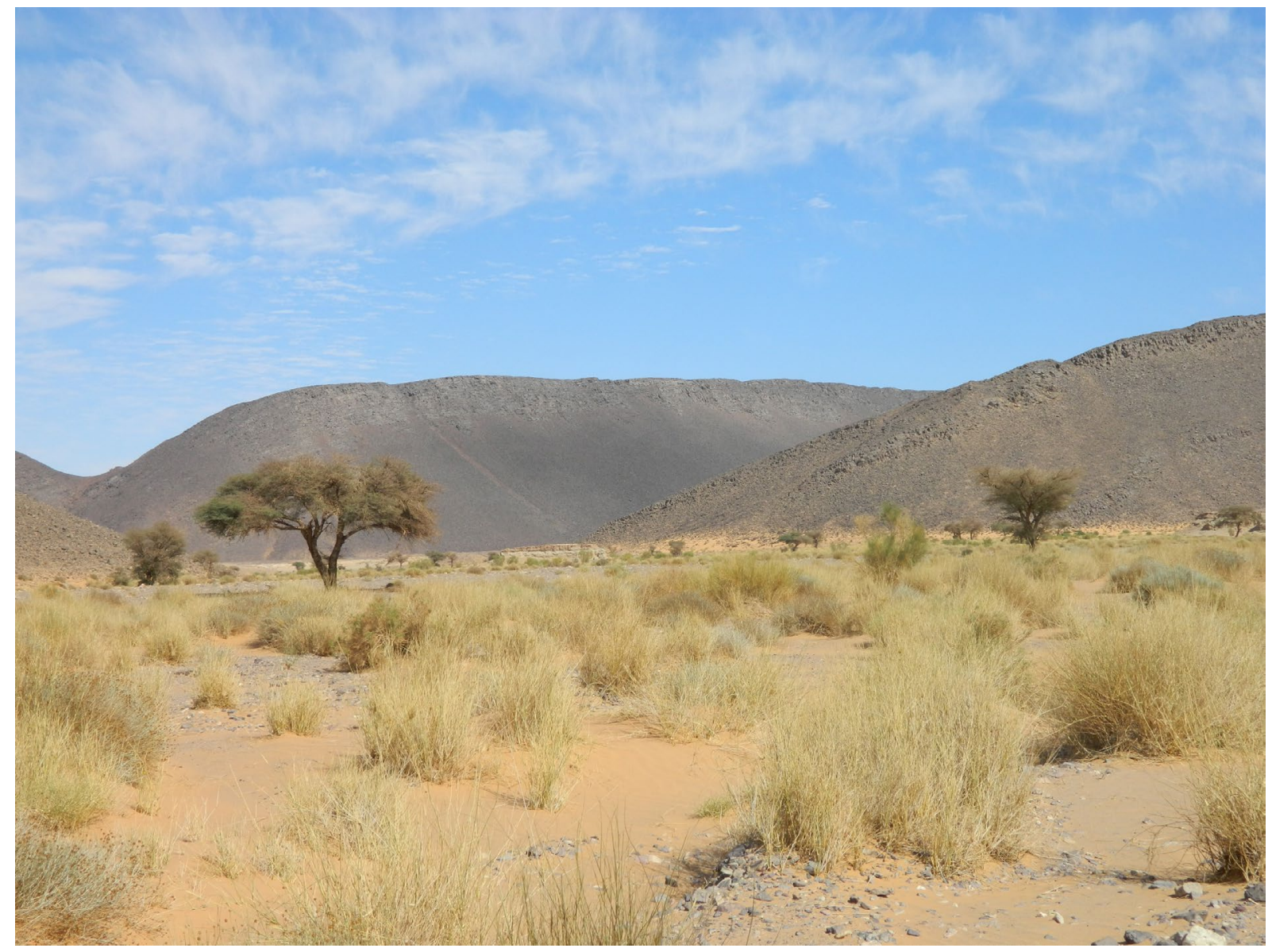

Figure 6. The Acacia tortilis var. raddiana, Panicum turgidum and Foleyola billotii association Quézel 1965, Ougarta, A.N. Benghanem, 31 March 2014.

\section{Discussion}

\section{Phytoecological characterization of plant communities with Acacia tortilis var. raddiana}

The differences between the two associations with Acacia tortilis var. raddiana existing in the northwestern Algerian Sahara are related to the different geomorphological characteristics of the wadi and their substrates. These gradients are closely linked to water availability, a crucial limiting factor in arid environments (Abd El-Ghani 1998; Fossati, Pautou, and Peltier 1998; Kadmon and Danin 1999; Ali, Dickinson, and Murphy 2000; Abd El-Ghani and Amer 2003; Brinkmann et al. 2009).

For the northwestern Sahara, Quézel (1965) describes this savanna through three associations of which two have been identified and thoroughly described in this work.

The comparison of the floristic relevés of the Acacia raddiana, Panicum turgidum and Foleyola billotii association shows that eight characteristic species from the 12 proposed by Quézel (1965) were not reported during the present investigation. Not only were many characteristic species proposed by Quézel (1965), but these are all characterized by both relatively low frequencies (between $6 \%$ and $20 \%$ ) and a wide geographical distribution of tropical Saharo-Arabian origin. In addition, Lavandula coronopifolia and Trichodesma africanum are typical species of rocky outcrops and therefore their identification by Quézel as characteristic species of the Acacia "pseudo-steppe" may have been mistaken, considering this ecological association.

With regard to Foleyola billotii, an endemic chamephyte of the Ougarta mountains and of southeastern Morocco, present in 35\% of the relevés published by Quézel (1965), was also absent from the relevés performed for the present study. The same species was also absent from the floristic lists of Quézel and Simonneau (1963), Barkoudah and Van Der Sar (1982), and Benhouhou, Dargie, and Gilbert (2003) for this association. However, it is important to note that field investigations conducted by Benghanem and Benhouhou (personal observation, 30 March 2014) have confirmed its presence - albeit at very low frequency - in our study area. This recent observation confirms the eastern boundary of its distribution in the Ougarta mountains (Quézel 1964, 1978).

The absence of these taxa, or failure to detect them, as seems to have been the case for Foleyola billotii, could be related to the increase in the intensity of certain anthropogenic activities (grazing and wood cutting). Hence, we would hypothesize that the vegetation ascribed in 


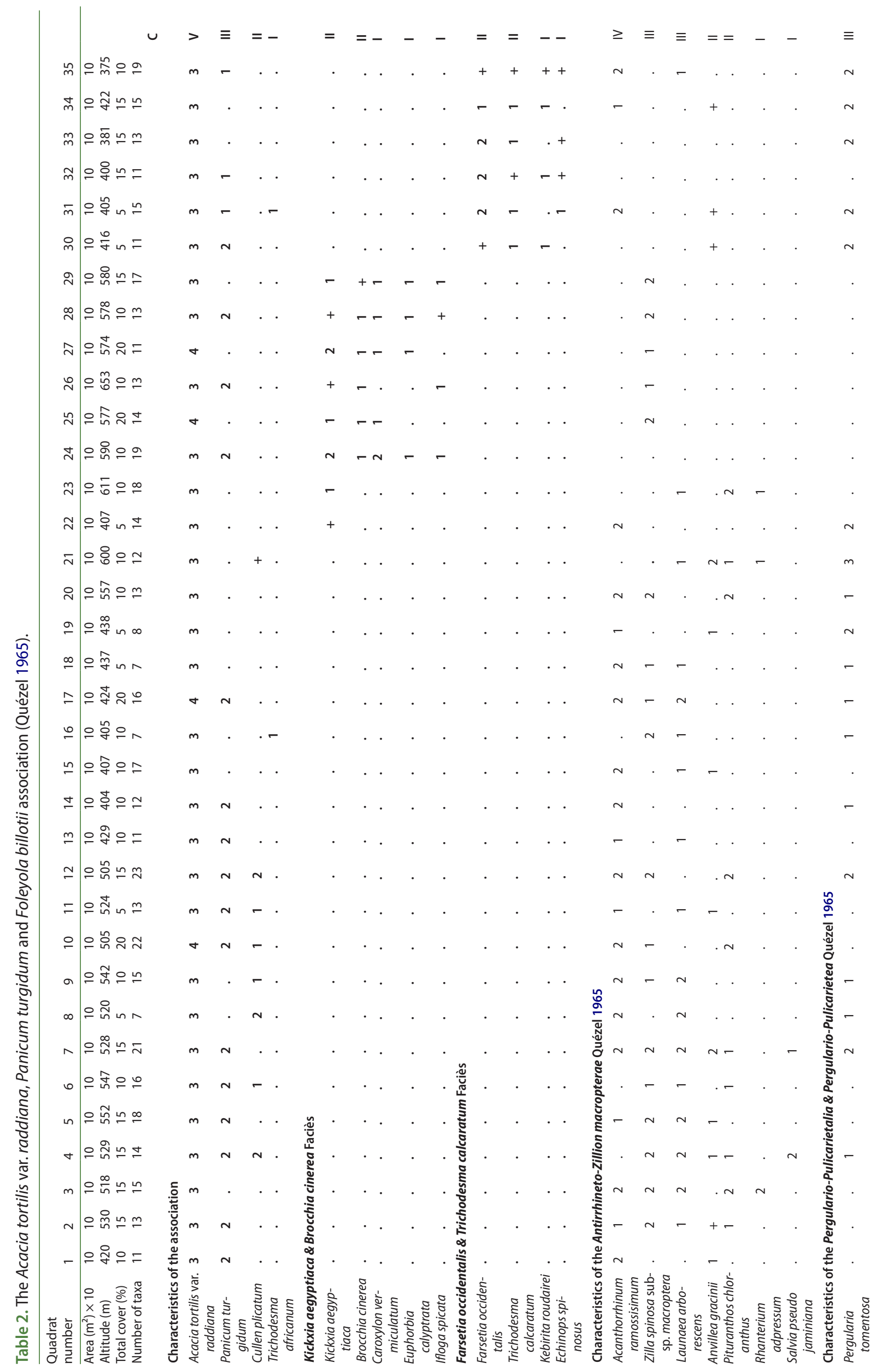




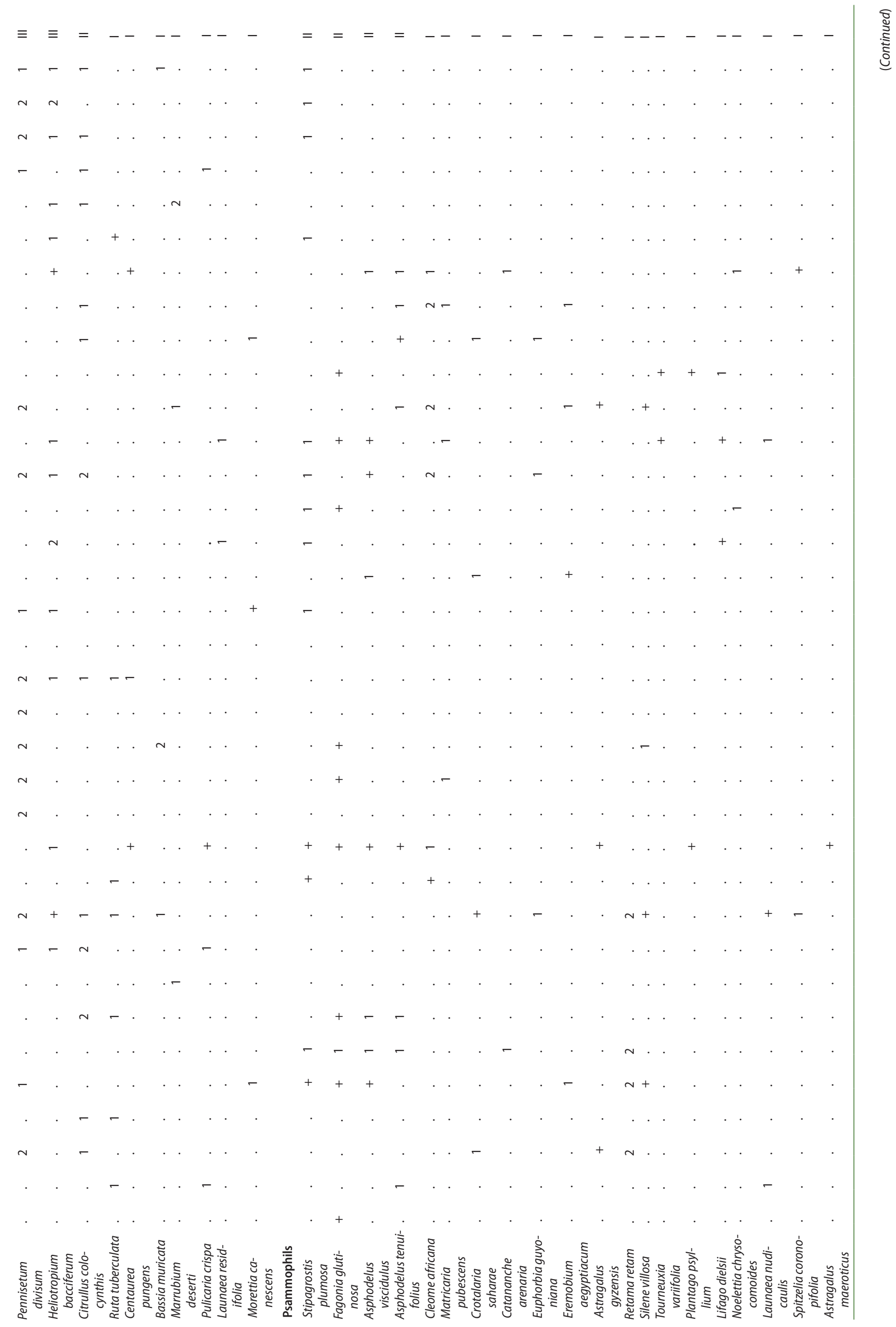




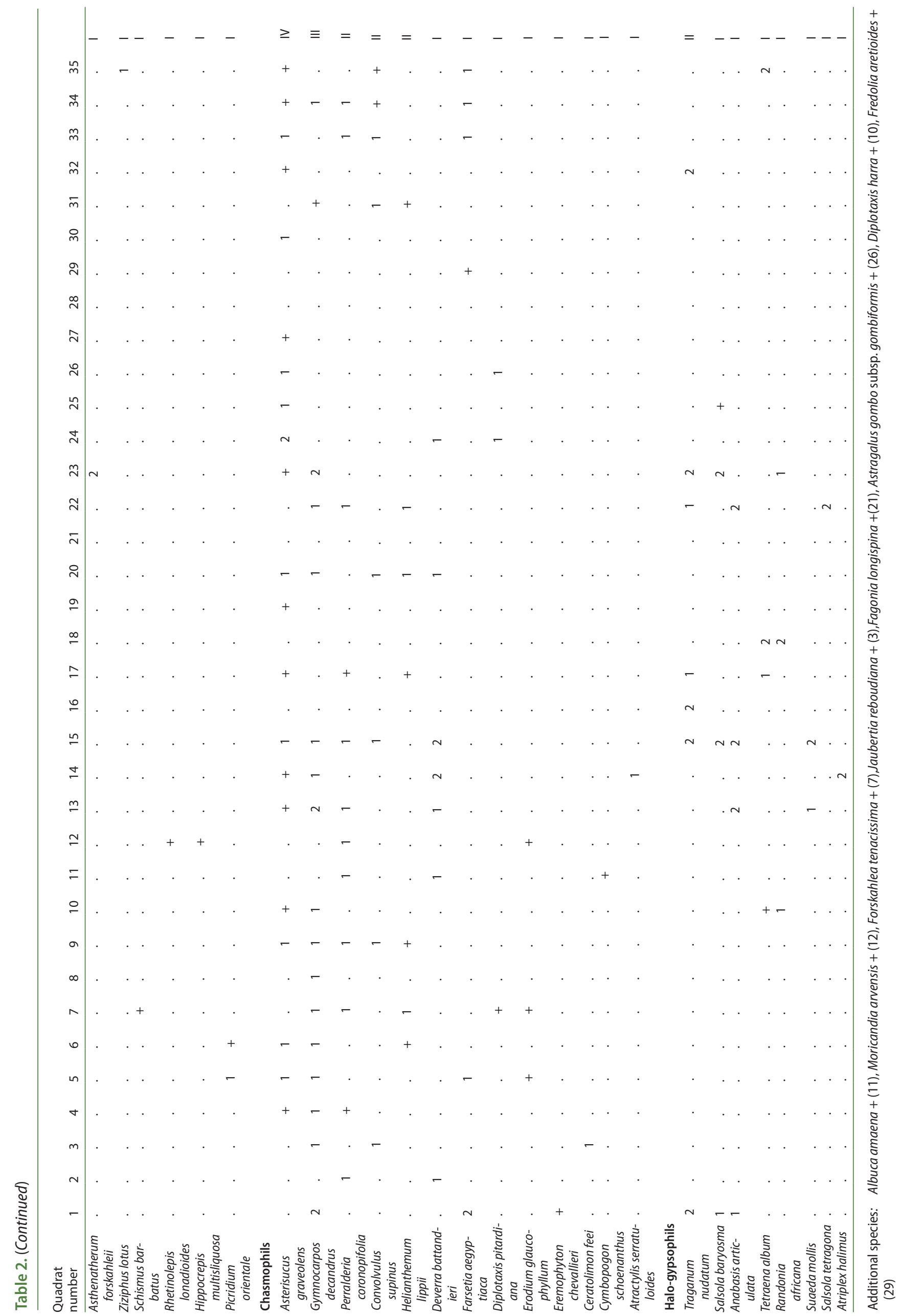




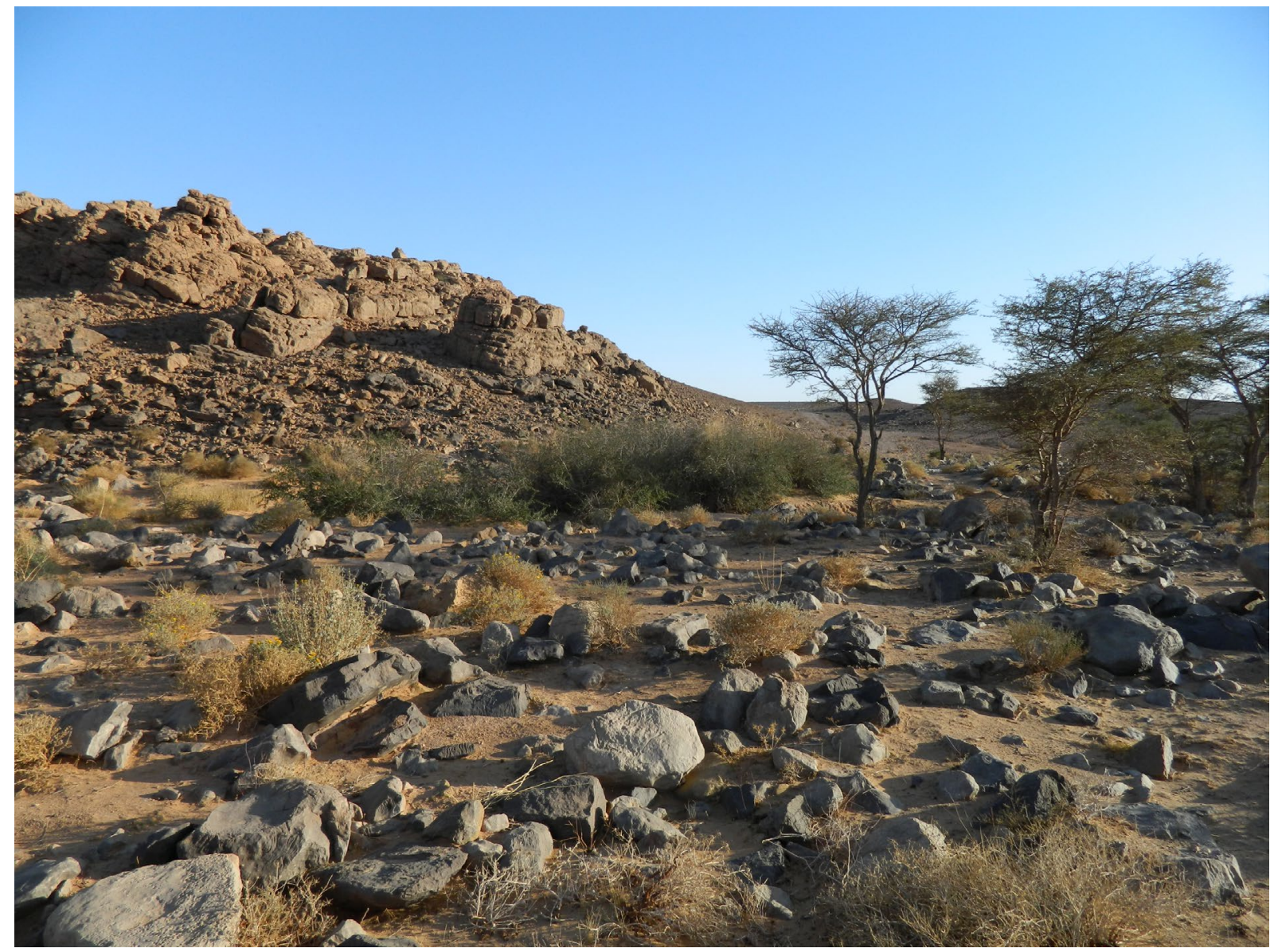

Figure 7. The Acacia tortilis var. raddiana and Rhus tripartita association Quézel 1965,Taghit, A.N. Benghanem, 27 March 2014.

this study to this association is a floristically impoverished ecological state, for which we propose to retain the following characteristic species: Acacia tortilis var. raddiana, Panicum turgidum and Cullen plicatum. Despite the floristic discrepancies between relevés published by Quézel (1965) and those from the present study, a detrended correspondence analysis confirmed that they correspond to the same association. Furthermore, the ecological variability of this association is again clearly illustrated along the first axis of Ffigure 8 where the rocky facies is at one end and the sandy facies at the other end of the axis 1 (Figure 8).

The Acacia tortilis var. raddiana and Rhus tripartita association was confirmed by this study in the northwestern Algerian Sahara, as being confined to rocky wadis and was less widely distributed than the previous one. Comparison between floristic lists published by Quézel and Simonneau (1963) and Quézel (1965) and those from the present study clearly indicates a lower frequency of two characteristic taxa for the latter: Rhus tripartita and Maytenus senegalensis. Considering the absence of two other characteristic taxa, Cenchrus ciliaris and Tricholaena teneriffae, from our relevés, their low frequency in the original association and their multiregional biogeographical distribution (Barry and Celles 1972-1973), their labelling as characteristic species seems no longer to be justified. Again, this is an impoverished version of the association where two species are absent and two others have low frequency, Maytenus senegalensis (I) and Rhus tripartita (II) (Table 3). The detrended correspondence analysis of the relevés published by Quézel (1965) and the current study confirm that we are dealing with the same association. The distribution of the relevés within the scattergram, where relevés made by Quézel (1965) are plotted at the positive end of the first axis, is due to the absence of Cenchrus ciliaris and Tricholaena teneriffae (Figure 9).

\section{Phytogeography of plant communities with Acacia tortilis var. raddiana}

These present results enable us to precisely describe the geographical limits of the Acacia raddiana, Panicum turgidum and Foleyola billotii association. Its eastern boundaries correspond to the eastern fringes of the Ougarta mountains because further east, in the northern Sahara subdivision, Foleyola billotii is absent (Quézel 1978). Its western boundaries correspond to the eastern limits of the Acacia raddiana and Foleyola billotii association described by Quézel et al. (1995) from the middle valley of the Draa in Morocco. The southern limits of the association correspond to the Kerzaz region, $100 \mathrm{~km}$ south of Béni-Abbès. Further south, both climatic and edaphic conditions prevent the development of 


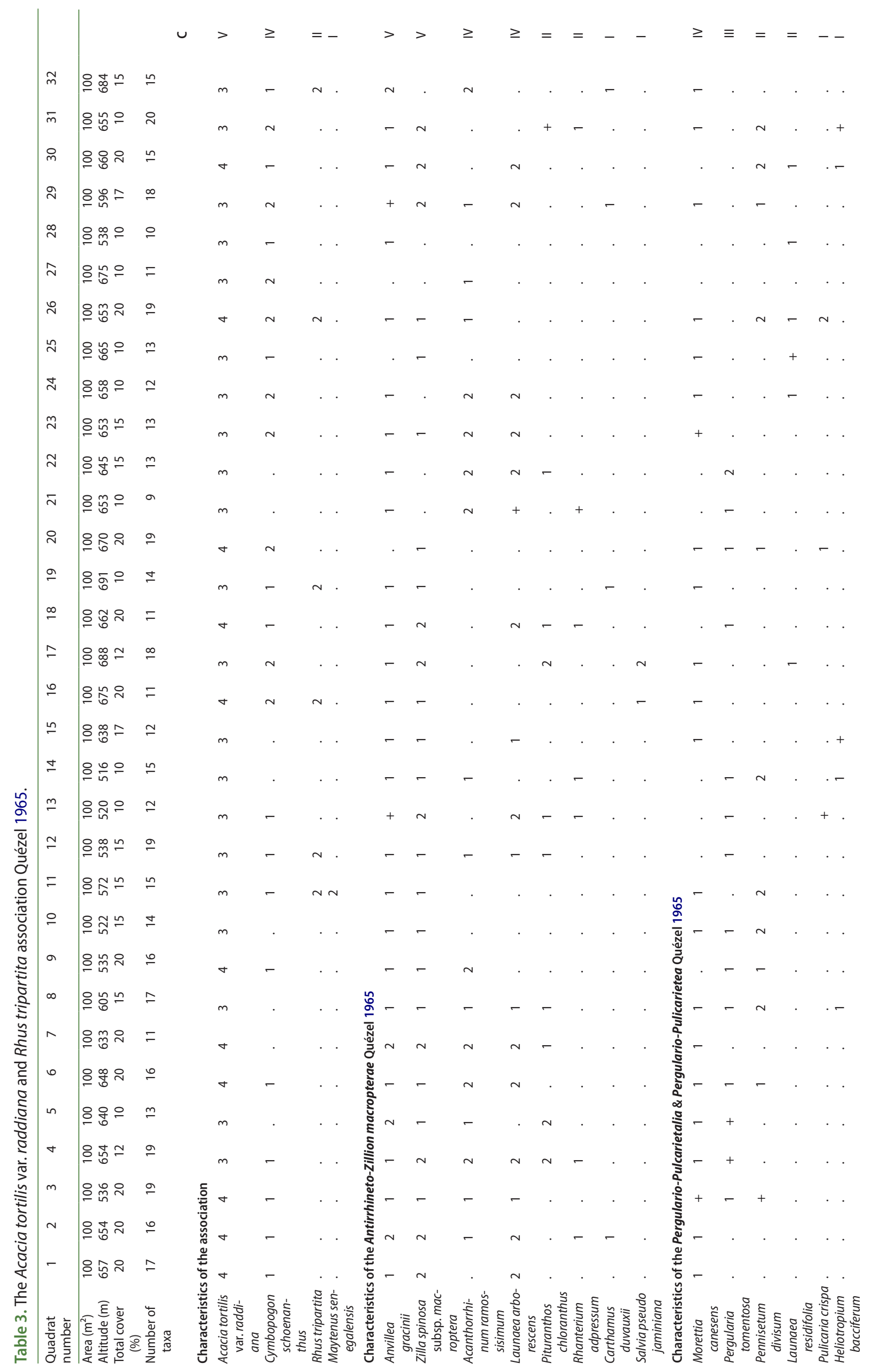




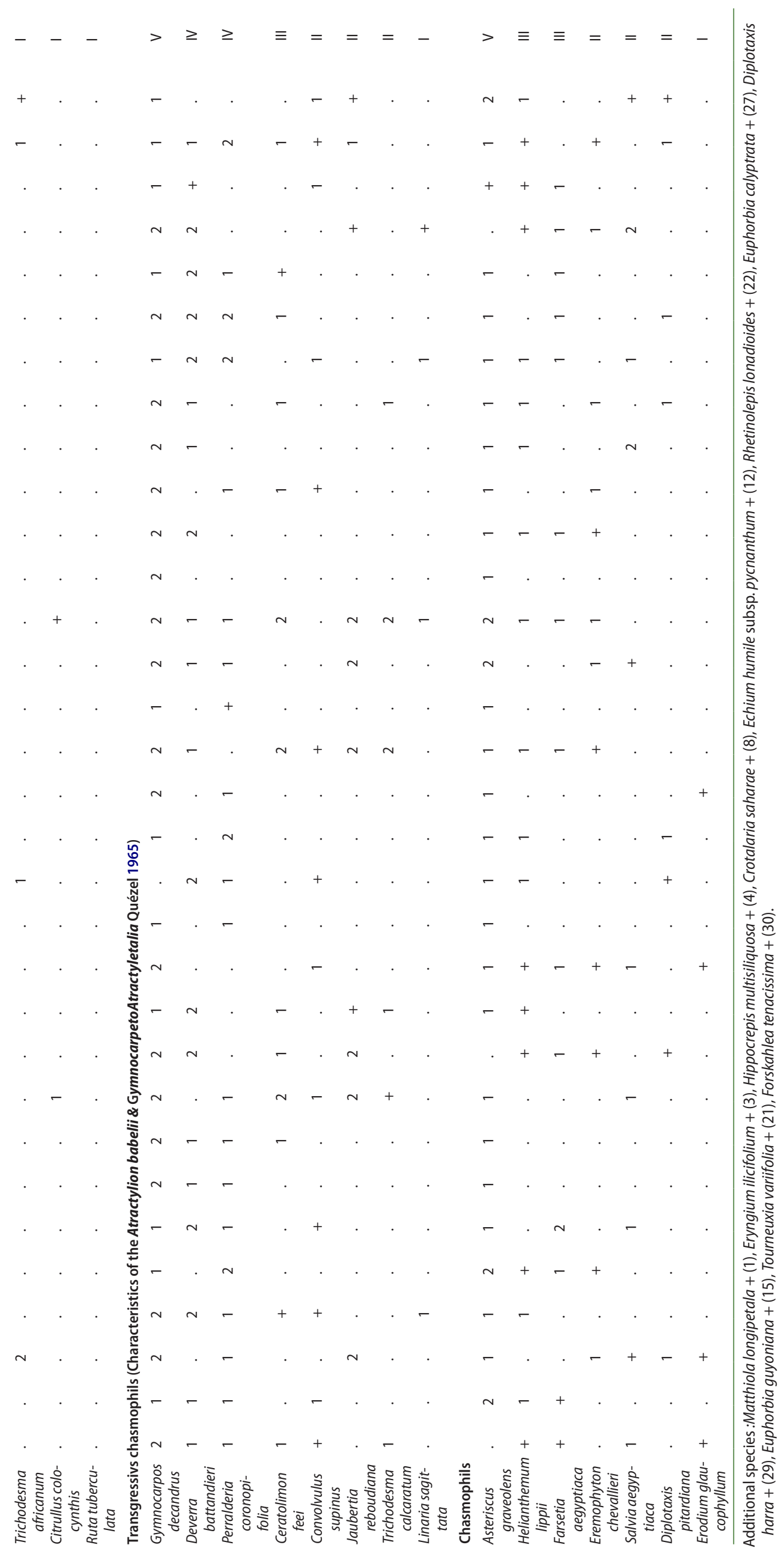




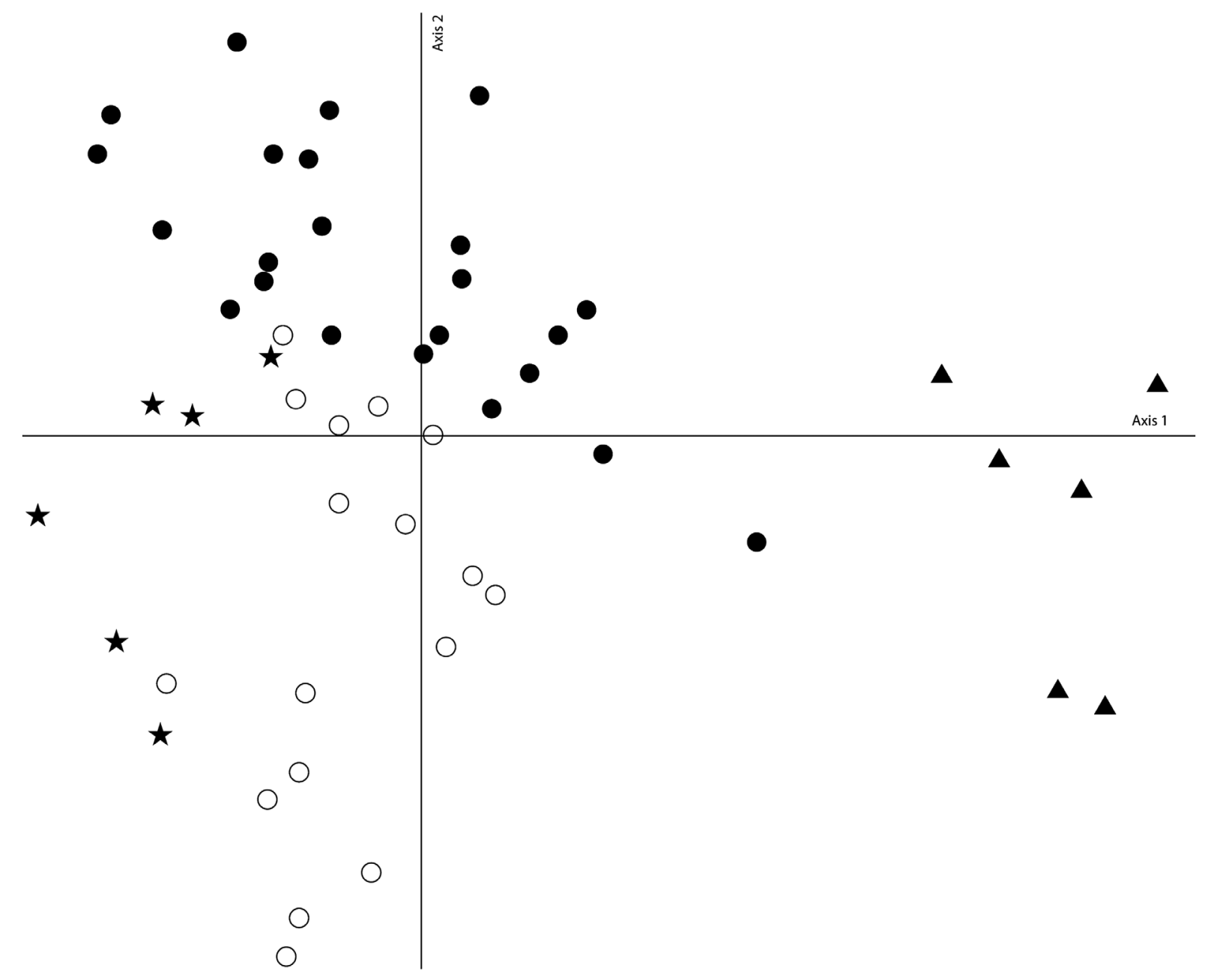

Relevés of Acacia tortilis var. raddiana, Panicum turgidum \& Foleyola billotii published by Quézel (1965).

$\Delta \star$ Relevés of Acacia tortilis var. raddiana \& Panicum turgidum of the current study.

Figure 8. A comparative DCA of the Acacia tortilis var. raddiana, Panicum turgidum and Foleyola billotii association relevés (Current study vs. Quézel 1965).

well-established Acacia savanna. As for its northern limit at the northeastern area of its distribution, it is located in the Béchar region, $150 \mathrm{~km}$ north of Béni-Abbès. The geographical distribution of the Acacia tortilis var. raddiana and Rhus tripartita association is relatively limited in area and corresponds to zones characterized by the rocky slopes of the djebels between Béchar in the north and Kerzaz in the south.

Further south, in the central Sahara, the desertic Acacia savanna corresponds to a different type - related to the Acacio-Panicion alliance Quézel 1965. Above the alliance level, this unit belongs to the same higher phytosociological units as the two associations described in this study. In this alliance, six Acacia associations are described, with the most common and widespread being the Senna italica and Panicum turgidum association Quézel 1965 that grows on gravelly-sandy substrates. The four other associations described by Quézel (1965) have smaller geographical distributions and are found on gravelly to sandy wadi beds. The sixth Acacia association, the Acacia tortilis var. raddiana and Salvadora persica Boucheneb and Benhouhou 2012, is closely associated with large wadi beds south of Tamanrasset and only develops where there are deep sandy compact soils (Table 4).

All of these associations, dominated by Acacia tortilis var. raddiana and Panicum turgidum, in the Algerian Sahara, share a common background flora with species such as: Heliotropium bacciferum, Asteriscus graveolens, Cymbopogon schoenanthus, Morettia canescens, Pergularia tomentosa, Farsetia aegyptiaca and Kickxia aegyptiaca (Maire 1940; Leredde 1957; Guinet 1958; Quézel 1964, 1965; Barry and Celles 1972-73; Barkoudah and Van Der Sar 1982; Ozenda 2004; Boucheneb and Benhouhou 2012).

This common background flora is also found elsewhere in the Saharo-Arabian region (Bornkamm and Kehl 1990; Quézel et al. 1995; Léonard 2001; 


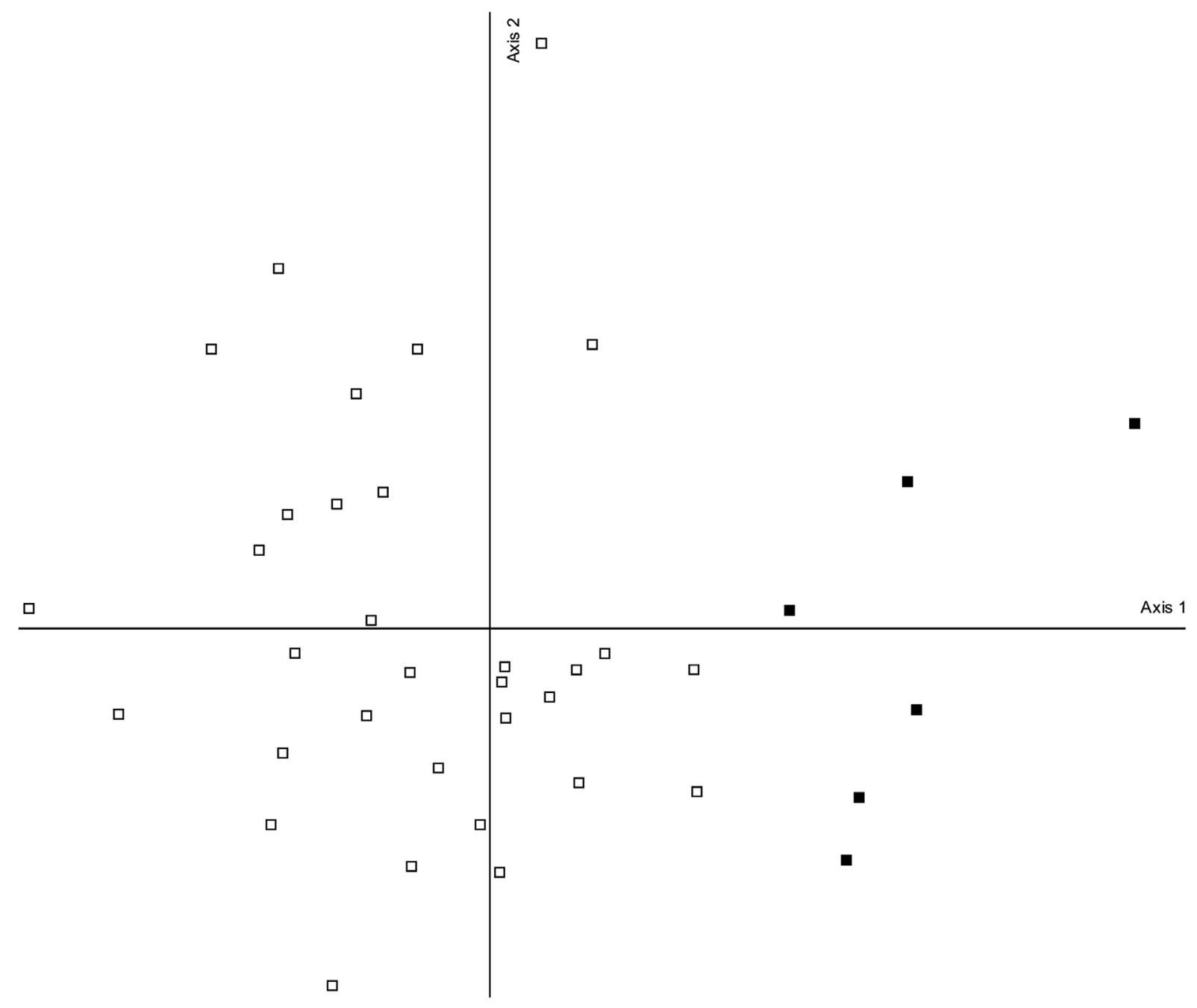

Relevés of Acacia tortilis var. raddiana \& Rhus tripartita published by Quézel (1965).

Relevés of Acacia tortilis var. raddiana \& Rhus tripartita of the current study.

Figure 9. A comparative DCA of the Acacia tortilis var. raddiana and Rhus tripartita association relevés (Current study vs. Quézel 1965).

Munzbergova and Ward 2002; Grouzis and Le Floc'h 2003; Brinkmann et al. 2009). These Acacia communities described by the different authors differ principally in the proportion of taxa assigned to the main biogeographical groups: Saharo-Mediterranean and Mediterranean in the west and north of the Sahara, Soudano-Deccanian in the south, Irano-Turanian in the east and Saharan endemics depending on the geographical zone considered (Zohary 1973; Danin 1983; Batanouny 1987; El Demerdash, Hegazy, and Zilay 1995; Abd El-Ghani 1996; Abd El-Ghani and Amer 2003; Anthelme, Waziri Mato, and Maley 2008; Al-Atar, El-Sheïkh, and Thomas 2012).

\section{General conclusion}

Acacia tortilis var. raddiana and Panicum turgidum constitute probably the keystone species of the Acacia savanna in the northwestern and central Sahara. Each of the main geographical subdivisions of the Sahara is distinguished by subtle ecological variations highlighted by floristic differences. From this basis, and as also suggested by recent syntaxonomical studies (Boucheneb and Benhouhou 2012; Abdelkrim, Zeraia, and Bensettiti 2014), the current phytosociological framework needed to be re-examined in order to propose a clearer syntaxonomic hierarchy of the Acacia tortilis var. raddiana communities in the Algerian Sahara, and the whole Sahara desert. For instance, as far as the third association (Acacia tortilis var. raddiana and Ziziphus lotus Quézel 1965) related the Antirrhineto-Zillion that Quézel (1965) found in the northwestern Sahara, relevés from the present study did not confirm its existence. Results suggest merging this third association with the Acacia raddiana, Panicum turgidum and Foleyola billotii association. In other words, it may be better to rationalize the Acacia tortilis var. raddiana savanna of the northwestern Sahara into two associations within which several 
Table 4. Acacia tortilis var. raddiana associations in the Algerian Sahara.

\begin{tabular}{|c|c|c|c|c|c|c|}
\hline Class & Order & Alliance & $\begin{array}{l}\text { Acacia tortilis var. raddiana } \\
\text { associations }\end{array}$ & Ecology & Localisation & Author(s) \\
\hline $\begin{array}{l}\text { Pergulario-Pulica- } \\
\text { rietea }\end{array}$ & $\begin{array}{l}\text { Pergulario-Pulicari- } \\
\text { etalia }\end{array}$ & $\begin{array}{l}\text { Antirrhineto- } \\
\text { Zillion } \\
\text { macropterae }\end{array}$ & $\begin{array}{l}\text { Acacia tortilis var. raddiana, } \\
\text { Panicum turgidum and } \\
\text { Foleyola billotii }\end{array}$ & $\begin{array}{l}\text { Gravelly-sandy } \\
\text { wadis }\end{array}$ & $\begin{array}{l}\text { Northwestern } \\
\text { Algerian Sahara }\end{array}$ & Quézel (1965) \\
\hline \multirow[t]{8}{*}{ Quézel 1965} & \multirow[t]{8}{*}{ Quézel 1965} & \multirow[t]{2}{*}{ Quézel 1965} & $\begin{array}{l}\text { Saxicolous facies : Farsetia } \\
\text { occidentalis and Trichodes- } \\
\text { ma calcaratum } \\
\text { Psammophilous facies: } \\
\text { Kickxia aegyptiaca and } \\
\text { Brocchia cinerea }\end{array}$ & & & \\
\hline & & & $\begin{array}{l}\text { Acacia tortilis var. raddiana } \\
\text { and Rhus tripartita }\end{array}$ & Rocky wadis & & \\
\hline & & \multirow[t]{6}{*}{$\begin{array}{l}\text { Acacio-Panicion } \\
\text { Quézel } 1965\end{array}$} & $\begin{array}{l}\text { Senna italica and Panicum } \\
\text { turgidum }\end{array}$ & $\begin{array}{l}\text { Gravelly-sandy } \\
\text { wadis }\end{array}$ & \multirow[t]{6}{*}{$\begin{array}{l}\text { Algerian central } \\
\text { Sahara }\end{array}$} & \\
\hline & & & $\begin{array}{l}\text { Senna alexandrina and } \\
\text { Tephrosia purpurea subsp. } \\
\text { leptostachya }\end{array}$ & Gravelly wadis & & \\
\hline & & & $\begin{array}{l}\text { Solenostemma arghel and } \\
\text { Acacia ehrenbergiana }\end{array}$ & Rocky cliffs & & \\
\hline & & & $\begin{array}{l}\text { Leptadenia pyrotechnica and } \\
\text { Chrozophora brocchiana }\end{array}$ & $\begin{array}{l}\text { Shallow compact } \\
\text { sand wadis }\end{array}$ & & \\
\hline & & & $\begin{array}{l}\text { Cullen plicatum and Hyoscy- } \\
\text { amus muticus }\end{array}$ & $\begin{array}{l}\text { Gravelly to } \\
\text { gravelly-sandy } \\
\text { wadis }\end{array}$ & & \\
\hline & & & $\begin{array}{l}\text { Acacia tortilis var. raddiana } \\
\text { and Salvadora persica }\end{array}$ & $\begin{array}{l}\text { Deep sandy com- } \\
\text { pact wadis }\end{array}$ & & $\begin{array}{l}\text { Boucheneb and } \\
\text { Benhouhou } \\
\text { (2012) }\end{array}$ \\
\hline
\end{tabular}

facies could be identified (according to local topographical and edaphic parameters). Also, is it necessary to define two different alliances, Antirrhineto-Zillion for the northwestern Sahara and Acacio-Panicion for the central Sahara, when they are so floristically similar to each other? Results of our study support this approach but need to be confirmed by further field investigations.

\section{Acknowledgements}

We would like to thank Benhamza Abdelmalek for providing the logistical assistance which enabled us to undertake the fieldwork. Our gratitude goes particularly to our guides Boudjemâa Bouzidi, Belkacem Telhaoui and Kebir Abdelkader.

\section{Disclosure statement}

No potential conflict of interest was reported by the authors.

\section{Notes on contributors}

Abdelkader Nabil Benghanem is a lecturer at the University of Mouloud Mammeri of Tizi-Ouzou (Algeria) since 2010. He is currently preparing his $\mathrm{PhD}$ thesis on Acacia tortilis var. raddiana communities in the Algerian Sahara. Contribution: data collecting, data analysis and writing the manuscript.

Nacéra Boucheneb is a researcher at the National Institute of Forestery Research (Algeria) since 1990. She worked for ten years in Tamanrasset before returning to Algiers. Contribution: her field experience and knowledge helped in the phytosociological analysis and the general discussion of the submitted paper.

Salima Benhouhou is a professor at the National High School of Agriculture (Algeria) since 1991. She gained her Saharan experience from 1987 when starting her $\mathrm{PhD}$ research on the vegetation in the northwestern part of the Algerian Sahara. Contribution: partly field data collection and the supervision of the general framework of the paper.

Brendan O'Hanrahan is a freelance ecologist who graduated from Aberdeen University (UK). Contribution: participated at the beginning of field data sampling, helped in the general discussion, particularly the ecological approach and his perfect mastery of the English language has facilitated the writing of this article and meeting the level of quality required by the Botany Letters.

Frédéric Médail is a professor at the Mediterranean Institute of marine and terrestrial Biodiversity and Ecology (France). Contribution: his experience in the Saharan domain helped greatly to improve the present paper with an in-depth reflection on data interpretation and the general discussion.

\section{References}

Abd El-Ghani, M. M. 1996. "Vegetation along a Transect in the Hijaz Mountains (Saudi Arabia)." Journal of Arid Environments 32: 289-304.

Abd El-Ghani, M. M. 1998. "Environmental Correlates of Species Distribution in Arid Ecosystems of Eastern Egypt." Journal of Arid Environments 38: 297-313.

Abd El-Ghani, M. M., and W. M. Amer. 2003. "SoilVegetation Relationships in a Coastal Desert Plain of Southern Sinai, Egypt." Journal of Arid Environments 55: 607-628.

Abdelkrim, H., L. Zeraia, and F. Bensettiti. 2014. “Contribution à Létude De La Flore Et De La Végétation Des Oueds Des Massifs De La Taessa Et De La Tefedest Dans L'Ahaggar (Sahara Central Algérie). Syntaxonomie Et Phytodiversité. Actes Du Colloque Du Centenaire De La Phytosociologie, Brest, Novembre 2010." Documents Phytosociologiques 3 (1): 33-42.

Aït-Ouali, R., and A. Nedjari. 2006. "Ougarta's Basin : A Permanent Mobility during the Paleozoic." Mémoire Du Service Géologique National 13: 23-40. 
Al-Atar, A., M. A. El-Sheikh, and J. Thomas. 2012. "Vegetation Analysis of Wadi Al-Jufair, a Hyper-Arid Region in Najd, Saudi Arabia." Saudi Journal of Biological Sciences 19: 357368.

Ali, M. M., G. Dickinson, and K. J. Murphy. 2000. "Predictors of Plant Diversity in a Hyperarid Desert Wadi Ecosystem." Journal of Arid Environments 55: 607-628.

Anthelme, F., M. Waziri Mato, and J. Maley. 2008. "Elevation and Local Refuges Ensure Persistence of Mountain Specific Vegetation in the Nigerian Sahara." Journal of Arid Environments 72: 2232-2242.

Barkoudah, Y., and D. Van Der Sar. 1982. "L'Acacia Raddiana Dans La Région De Béni-Abbès." Bulletin De La Société D'Histoire Naturelle De L'Afrique Du Nord 70 (1-4): 79121.

Barry, J. P., and J. C. Celles. 1972-73."Le Problème Des Divisions Bioclimatiques Et Floristiques $\mathrm{Au}$ Sahara Algérien." Naturalia Monspeliensia, Série Botanique (23 24): 5-48.

Barry, J. P., J. C. Celles, and R. Manière. 1981. "Le Problème Des Divisions Bioclimatiques Et Floristiques Au Sahara Algérien. Note III: Lanalyse De La Végétation De La Région D'In-Salah Et De Tamanrasset (Sahara Central Et Méridional)." Naturalia Monspeliensia, Serie Botanique 44: $1-48$.

Batanouny, K. H. 1987. “Current Knowledge of Plant Ecology in the Arab Gulf Countries." Catena 14: 291-316.

Benghanem, A. N. 2009. "Étude écologique Des Formations à Acacia Tortilis Ssp. Raddiana Dans La Région De BéniAbbès (Wilaya De Béchar)." Master diss., University of Sciences \& Technlogy Houari Boumédiène. Algiers.

Benhouhou, S. S. 1991. Vegetation Studies in the Algerian Sahara. PhD Diss.: University of Sheffield.

Benhouhou, S. S., T. C. D. Dargie, and O. L. Gilbert. 2001. "Vegetation Association in the Great Western Erg and the Saoura Valley, Algeria." Phytocoenologia 31 (3): 311-324.

Benhouhou, S. S., T. C. D. Dargie, and O. L. Gilbert. 2003. "Vegetation Associations in the Ougarta Mountains and Dayas of the Guir Hamada, Algerian Sahara." Journal of Arid Environments 54: 739-753.

Bensaïd, S., L. Aït-Mohand, and B. Echaïb. 1996. "Évolution Spatio-Temporelle Des Peuplements D’Acacia Tortilis (Forsk.) Hayne Raddiana (Savi) Brenan Dans Les Monts De L'Ougarta (Sahara Nord-Occidental)." Sécheresse 7: 173-178.

Bornkamm, R., and H. Kehl. 1990. "The Plant Communities of the Western Desert of Egypt.” Phytocoenologia 19 (2): 149-231.

Boucheneb, N., and S. S. Benhouhou. 2012. "Plant Communities in the Tamanrasset Region, Ahaggar, Algeria." Ecologia Mediterranea 38: 67-80.

Boulos, L. 1995. "Notes on Acacia. Studies in the Leguminoseae of Arabia." Kew Bulletin 50 (2): 327-337.

Braun-Blanquet, J. 1952. Groupements Végétaux De La France Méditerranéenne. Paris: Centre National de la Recherche Scientifique.

Brenan, J. P. M. 1983. Manual on Taxonomy of Acacia Species. Rome: Food and Agriculture Organization of the United Nations.

Brinkmann, K., and A. Patzelt., U. Dickhoefer., E. Schlecht, and A. Buerkert. 2009. "Vegetation Patterns and Diversity along an Altitudinal and a Grazing Gradient in the Jabal Al Akhdar Mountain Range of Northern Oman." Journal of Arid Environments 73: 1035-1045.

Conrad, G., and A. R. Roche. 1965. "Étude Stratigraphique Et Hydrogéologique De Lextrémité Méridionale De La
Hammada Du Guir." Bulletin De La Société Géologique De France VII 7: 695-712.

Danin, A. 1983. Desert Vegetation of Israel and Sinai. Jerusalem: Cana publishing house.

Dobignard, A., and C. Chatelain. 2010-13. Index Synonymique De La Flore D’Afrique Du Nord. 5 vols. Geneva: Editions des Conservatoire et Jardin botaniques de la ville de Genève.

Dubief, J. 1959. Le Climat Du Sahara. 2 vols. Alger. Mémoires de l'Institut de Recherche Saharienne. Université d'Alger.

Dutil, P. 1971. Contribution à Létude Des Sols Et Des Paléosols Sahariens. PhD Diss.: University of Strasbourg.

El-Demerdash, M. A., A. K. Hegazy, and A. M. Zilay. 1995. "Vegetation-Soil Relationship in Tihamah Coastal Plains of Jazan Region, Saudi Arabia." Journal of Arid Environments 30 (2): 161-174.

Fossati, J., G. Pautou, and J. P. Peltier. 1998. "Wadi Vegetation of the North-Eastern Desert of Egypt." Feddes Repertorium 109 (3-4): 313-327.

Gaci, D. 2012. "Étude écologique Des Formations à Acacia Tortilis Subsp. Raddiana Dans La Région De Tamanrasset." Master diss., University of Sciences \& Technlogy Houari Boumédiène. Algiers.

Grouzis, M., and E. Le Floc'h. 2003. Un Arbre Au Désert Acacia Raddiana. Paris: Institut pour la Recherche et le Développement.

Guinet, Ph. 1954. Carte De La Végétation De L’Algérie: Feuille De Béni-Abbès Au 1/200.000. Paris: Institut Géographique National.

Guinet, Ph. 1958. "Notice Détaillée De La Feuille Béni-Abbès (Coupure Spéciale)." Bulletin Du Service De La Carte Phytogéographique Série a Carte De La Végétation III (1): 21-96.

Guinet, Ph, and Ch Sauvage. 1954. "Les Hamada SudMarocaines: Botanique." Travaux De L'Institut Scientifique Chérifien, Série Générale 3: 75-167.

Guinochet, M., and P. Quézel. 1954. "Reconnaissance Phytosociologique Autour Du Grand Erg Occidental.” Institut Des Travaux De Recherches Sahariennes 12: 11-27.

Hill, M. O., and H. G. Gauch. 1980. "Detrended Correspondence Analysis: An Improved Ordination Technique." Vegetatio 42: 47-58.

Kadmon, R., and A. Danin. 1999. "Distribution of Plant Species in Relation to Spatial Variation in Rainfall." Journal of Vegetation Science 10: 421-432.

Kassas, M. 1953. "Habitat and Plant Communities in Egyptian Desert : II. the Features of Desert Community." Journal of Ecology 41: 248-256.

Kennenni, L. 1991. "Geography and Phytosociology of Acacia Tortilis in the Sudan." African Journal of Ecology 29: 1-10.

Le Houérou, H. N. 1990. “Définition Et Limites Bioclimatiques Au Sahara." Sécheresse 1: 246-259.

Le Houérou, H. N. 1995. "Considérations Biogéographiques Sur Les Steppes Arides De L'Afrique Du Nord.” Sécheresse 6: 167-182.

Leredde, C. 1957. "Étude écologique Et Phytogéographique Du Tassili Des Ajjer." Travaux De L'Institut Des Recherches Sahariennes 2: 259-381.

Léonard, J. 2001. Flore Et Végétation Du Jebel Uweinat (Désert De Libye, Egypte, Soudan). Bruxelles: Jardin Botanique National de Belgique.

Maire, R. 1938. "La Flore Et La Végétation Du Sahara Occidental." Mémoires De La Société De Biogéographie 6: 325-333.

Maire, R. 1940. "Étude Sur La Flore Et La Végétation Du Sahara Central." Mémoires De La Société D'Histoire Naturelle De L'Afrique Du Nord 3: 273-433. 
Mc Cune, B., and M. J. M. Mefford. 1999. PC-ORD Version 4: Multivariate Analysis Ecological Data. Glenden Beach, OR: MJM Software Design.

Munzbergova, Z., and D. Ward. 2002. "Acacia Trees as Keystone Species in Negev Desert Ecosystems." Journal of Vegetation Science 13 (2): 227-236.

Nedjari, A. 1995. "Les événements Paléosols Dans Le Bassin Permo-Carbonifère De Béchar (Sahara Algérien). Une Approche Géodynamique." Bassins Sédimentaires Africains: Géodynamique Et Géologie Séquentielle, Biominéralisation, Sédimentation Et Organismes 118: 300-321.

Ozenda, P. 1958. "La Végétation Ligneuse Du Sahara." Cahiers Rivières Et Forêts 9 (10): 65-75.

Ozenda, P. 2004. Flore Et Végétation Du Sahara. 3rd ed. Paris: Éditions du Centre National de la Recherche Scientifique.

Quézel, P. 1964. "Contribution à Létude De Lendémisme Chez Les Phanérogames Sahariens." Compte Rendu Des Séances De La Société De Biogéographie. 339: 89-103.

Quézel, P. 1965. La Végétation Du Sahara. Du Tchad à La Mauritanie. Stuttgart: Gustav Fischer Verlag.

Quézel, P. 1978. "Analysis of the Flora of Mediterranean and Saharan Africa." Annals of the Missouri Botanical Garden 65 (2): 479-534.
Quézel, P., and P. Simonneau. 1963. "Les Peuplements D'Acacia Du Sahara Nord-Occidental : Etude Phytosociologique." Travaux De L'Institut De Recherches Sahariennes 20: 79-121.

Quézel, P., M. Barbéro, A. Benabid, and S. Rivas-Martinez. 1995. "Les Structures De Végétation Arborées à Acacia Sur Le Revers Méridional De L'Anti-Atlas Et Dans La Vallée Inférieure Du Draa (Maroc)." Phytocoenologia 25: 279304.

Roche, M. A. 1973. "Hydrogéologie De La Haute Saoura (Sahara Nord-Occidental)." Bulletin Du Service Géologique De L'Algérie 43: 1-91.

Ross, J. H. 1981. "An Analysis of the African Acacia Species: Their Distribution, Possible Origin and Relationships." Bothalia 13: 389-413.

Ter Braak, C. J. F. 1987. "The Analysis of VegetationEnvironment Relationships by Canonical Correspondence Analysis." Vegetatio 69: 69-77.

Tits, D. 1925. "Le Sahara Occidental, Contribution Phytogéographique." Bulletin De La Société Royale De Botanique De Belgique 8: 39-91.

Zohary, M. 1973. Geobotanical Foundations of the Middle East. Stuttgart: Gustav Fischer Verlag. 